\title{
TRANSGENITALIZAÇÃO E ADEQUAÇÃO SOCIAL DOS TRANSEXUAIS
}

\author{
Diogo Rasia Escobar ${ }^{*}$
}

SUMÁRIO: Introdução; 2 Breves Apontamentos sobre os Direitos Humanos; 3 Transexualismo e Transgenitalização; 4 Bases Jurídicas para Alteração do Prenome e Sexo dos Transexuais; 5 Adequação Social dos Transexuais; 6 Conclusão; Referências.

RESUMO: A busca imperativa pelo ajuste sexual, daqueles inconformados com a sua sexualidade, caracteriza a síndrome do transexualismo como uma patologia. A transgenitalização apresenta-se como a única medida eficaz para adequar o sexo morfológico ao psicológico, eliminando a causa de repulsa que pode levar à automutilação e ao suicídio. $O$ procedimento cirúrgico compõe a primeira fase do tratamento indicado a esses indivíduos, o qual se completará com a adequação social do transexual redesignado, ajustando-se o antigo prenome e sexo ao novo corpo. Nesse ponto, reside a questão primordial do estudo, o direito de inserção social dos transexuais frente à relativa imutabilidade dos Registros Públicos, perquirindo-se sobre a viabilidade da pretensa alteração. O silêncio da Lei acerca da problemática não obsta soluções que, certamente, aflorarão quando transposto o caminho alicerçado nos pressupostos dos direitos humanos, da dignidade da pessoa humana, dos direitos da personalidade, dos objetivos da República Federativa do Brasil e da inviolabilidade dos direitos à vida, à liberdade, à igualdade e à saúde.

PALAVRAS-CHAVES: Adequação Social; Transexualismo; Transgenitalização.

\section{TRANSGENITALIZATION AND SOCIAL ADAPTATION OF TRANSSEXUAL PEOPLE}

ABSTRACT: The mandatory sexual adjustment of people who are non-conformed with their sexuality characterizes the transsexual syndrome as pathology. Transgenitalization is the only efficacious strategy for morphological sex to comply with the psychological one and thus eliminating the cause of repulsion that may lead to self-mutilation and suicide. Surgery is the first phase in the treatment which is complete through the social adaptation of the transsexual person by adjusting the former first name and sex to the body. The main issue of current analysis is the transsexual's right to social insertion in the face of the relative immutability of public registries and their inquiries on the viability of the intended change. The silence of

\footnotetext{
Mestre em Direitos Humanos pela Universidade Regional do Noroeste do Estado do Rio Grande do Sul (UNIJUÍ), Ijuí (RS), Brasil; E-mail: dyogoescobar@hotmail.com.
} 
the law with regard to this issue does not impede solutions that will certainly appear when the impairments contrary to the presuppositions of human rights, the dignity of the human person, the rights of the personality, the objectives of the republic and the inviolability of rights to life, equality and health are overcome.

KEY WORDS: Social Adaptation; Transexualism; Transgenitalization.

\section{TRANSGENITALIZACIÓN Y ADECUACIÓN SOCIAL DE LOS TRANSEXUALES}

RESUMEN: La búsqueda imperativa por el ajuste sexual, de aquellos inconformados con su sexualidad, caracteriza el síndrome del transexualismo como una patología. La transgenitalización se presenta como la única medida eficaz para adecuar el sexo morfológico al psicológico, eliminando la causa de repulsa que puede llevar a la automutilación y al suicidio. El procedimiento quirúrgico compone la primera fase del tratamiento indicado a estos individuos, el cual se completará con la adecuación social del transexual (re)designado, ajustando el antiguo prenombre y sexo al nuevo cuerpo. En este punto, reside la cuestión primordial del estudio, el derecho a la inserción social de los transexuales frente a la relativa inmunidad de los Registros Públicos, averiguándose la viabilidad de pretensa alteración. El silencio de la Ley sobre esa problemática no obsta soluciones que, ciertamente, van a aflorar cuando transpuesto el camino basado en los presupuestos de los derechos humanos, de la dignidad de la persona humana, de los derechos de personalidad, de los objetivos de la Republica Federativa de Brasil y de la inviolabilidad de los derechos a la vida, a la libertad, a la igualdad y a la salud.

PALABRAS-CLAVE: Adecuación Social; Transexualismo; Transgenitalización

\section{INTRODUÇÃO}

Em uma passagem da obra Romeu e Julieta, escrita aproximadamente entre 1591 e 1595, por Willian Shakespeare, destaca-se a seguinte passagem: o que há num simples nome? O que chamamos rosa, com outro nome não teria igual perfume?

Mas o que diria o poeta sobre os conflitos de identidade do ser humano moderno, em que indivíduos aprisionados em corpos do sexo oposto ao que acreditam pertencerem, denominados de transexuais, encontram na medicina os recursos para redefinir o corpo e no direito a possibilidade de adequá-lo socialmente, com um novo prenome e estado sexual. Assim, Julieta passa a ser Romeu e Romeu transforma-se em Julieta. 
Esse assunto demonstra a riqueza dos fatos sociais, e, por outro lado, a dificuldade de serem acompanhados pelo direito, que acaba sendo sufocado pelo dinamismo desses acontecimentos, mas que encontra nos princípios e nas cláusulas gerais o ar necessário para tratar de conflitos dessa natureza.

No ordenamento jurídico pátrio, os transexuais têm garantido o atendimento no âmbito do Sistema Único de Saúde, inclusive para processo transexualizador. Entretanto, após procedimento cirúrgico, surge a necessidade de alterações nos registros dessas pessoas, adequando-se o antigo prenome e sexo ao novo corpo. Porém, neste campo, não existe o mesmo respaldo normativo.

Dessa maneira, além da transformação física, mostra-se necessária uma transformação jurídica, sendo a análise dessa possibilidade o principal objetivo do presente estudo, mormente frente à imutabilidade relativa dos Registros Públicos.

Para tanto, pretende-se construir um caminho alicerçado nos direitos humanos, na dignidade humana, nos direitos da personalidade, nos objetivos da República Federativa do Brasil e na inviolabilidade dos direitos à vida, à liberdade $\mathrm{e}$ à igualdade. Salienta-se, de igual forma, o direito à saúde e o princípio da dignidade da pessoa humana, fundamento primordial de um Estado Democrático de Direito.

Embora o tema introduza outros problemas a ele conexos, limita-se o presente estudo a uma resposta acerca da possibilidade ou impossibilidade de alteração do prenome e de sexo dos transexuais no ordenamento pátrio após a transgenitalização.

\section{BREVES APONTAMENTOS SOBRE OS DIREITOS HUMANOS}

Antes de se abordar os fundamentos para alteração do prenome e sexo dos transexuais no ordenamento jurídico pátrio, pretende-se enfocar, ainda que brevemente, o tema dos direitos humanos, destacando-se a origem e a complexa discussão acerca da fundamentação desses preceitos.

Com isso, objetiva-se uma melhor compreensão do ser humano moderno, os problemas de identidade que enfrenta, bem como a sua constante busca por uma vida digna. Ainda, analisando a tutela da dignidade humana e da dignidade da pessoa humana como forma de garantia de vida digna, especialmente em um cenário complexo, no qual a ciência jurídica não acompanha o fato social, pretendese demonstrar que o direito continua sendo a melhor alternativa para tratar os conflitos contemporâneos. 
Destaca-se, nesse contexto, um recorte histórico a partir do Estado moderno, quando o indivíduo passa a ocupar o centro do mundo político, lugar reservado anteriormente ao Estado, invertendo-se, assim, a ideia de desigualdade e igualdade entre os homens. O Estado não é mais compreendido como resultado do desdobramento de comunidades menores, mas de um acordo entre indivíduos. O fundamento do poder, que residia em Deus ou na tradição até os séculos XVII e XVIII, passa a ser alicerçado no consenso dos indivíduos. Por fim, verifica-se que essas transformações de cunho político também interferem no mundo jurídico, deixando-se de se privilegiar os deveres para se declarar direitos. ${ }^{1}$

O Estado moderno se consolida incialmente como centralizado, soberano e absoluto, típico da estrutura dos séculos XVI e XVII. Contudo, esta estrutura passa a ser questionada até ser abandonada. Em decorrência desse processo, no final do século XVIII, surge o Estado moderno em sua versão liberal, inspirado em referências como as Revoluções Gloriosa (1688), Americana (1776) e Francesa (1789). Em que pese manter as características da centralidade e da soberania, o Estado passa a ser limitado por uma Constituição e por uma declaração de direitos. ${ }^{2}$

Conforme salienta Gilmar Antonio Bedin ${ }^{3}$, a luta pelos direitos humanos nasce de uma ruptura com o Estado moderno em sua visão absolutista e com a arbitrariedade por ele representada, originando, com isso: no século XVIII, os direitos civis ou negativos, estabelecidos contra o Estado; no século XIX, os direitos políticos ou positivos, de participar do Estado; no início do século XX, os direitos econômicos e sociais, vistos como direitos de crédito e que se dão através do Estado; e, no final da primeira metade do século XX, os direitos de solidariedade, entendidos como direitos sobre o Estado, os

${ }^{1}$ BEDIN, Gilmar Antônio. Os direitos do homem e o neoliberalismo. Ijuí: Ed. da Unijuí, 2002, p. 20-21.

2 BEDIN, Gilmar Antônio (Org.). Cidadania, direitos humanos e equidade. Ijuí: Ed. da Unijuí, 2012, p. 378-379.

3 BEDIN, op. cit., 2002, p. 42 e 104-105. 
quais demandam uma nova concepção de soberania e uma nova ordem internacional. ${ }^{4}$ Contudo, essas transformações que levaram o indivíduo a ser sujeito de uma infinidade de direitos, também levam a outra discussão, que diz respeito à necessidade de fundamentação dos direitos humanos ${ }^{5}$, visando à promoção e efetivação dessa categoria de direitos.

Nesse viés, a título ilustrativo, destacam-se quatro distintas formulações doutrinárias sobre a fundamentação dos direitos humanos: a proposta jusnaturalista;

${ }^{4}$ Esclarecendo melhor a questão, o autor refere que os direitos civis ou negativos são estabelecidos contra o Estado, instituindo-se um marco divisório entre esfera pública (Estado) e esfera privada (sociedade civil), dessa distincão, estrutura-se o pensamento liberal e posteriormente o democrático. Dentre esses direitos, destacamse as liberdades físicas, de expressão, de consciência, o direito de propriedade privada, os direitos da pessoa acusada $\mathrm{e}$ as chamadas garantias dos direitos. Com a emergência do século XIX, a pauta passa às prerrogativas que levam a formação e constituição do poder político, representando o surgimento do ideário democrático e a superação da ideia de liberdade negativa, como não impedimento, pela ideia de liberdade positiva, como autonomia, como desejo de participar na formação e constituição do poder político, ou seja, a expansão do Estado moderno de sua versão liberal para sua forma democrática, destacando-se o direito ao sufrágio universal, de constituir partidos políticos, de plebiscito, de referendo e de iniciativa popular. Já nas últimas décadas do século XIX e nas primeiras do século XX, a consolidação da Revolução Industrial, a emergência da classe trabalhadora como força política e sua organizacão em partidos, o surgimento dos movimentos socialistas e as revoluções sociais trazem novos desafios ao Ëstado moderno, exigindo-se um intervencionismo na organização social, o que restou consolidado e aprimorado após a Segunda Guerra Mundial. Dessa forma, nasce o Estado de Bem-Estar Social. O constitucionalismo torna-se, com a Constituição Mexicana de 1917 e com a Constituição de Weimar de 1923, constitucionalismo social, resultando nos chamados direitos econômicos e sociais, que tornam o Estado devedor dos indivíduos e que são garantidos por meio do Estado. Essas prerrogativas podem ser dividias em duas ordens de direitos: $1^{\mathrm{a}}$ ) relativos ao homem trabalhador, direito à liberdade de trabalho, ao salário mínimo, à jornada de trabalho de 08 horas, ao descanso semanal remunerado, às férias anuais, à igualdade de salários para trabalhadores iguais, à liberdade sindical e o direito de greve; $2^{\mathrm{a}}$ ) relativos ao homem consumidor, direito à saúde, à educação, à seguridade social e o direito à habitação. (BEDIN, op. cit., 2012, p. 378-382). A quarta geracão de direitos surgiu no final da primeira metade do século XX, tendo como grande marco o ano de 1948 (data da Declaração Universal dos Direitos do Homem), e pode ser denominada de direitos de solidariedade, compreendendo os direitos do homem em âmbito internacional. Não são direitos contra o Estado, de participar do Estado ou por meio do Estado, mas direitos sobre o Estado. Dentre esses preceitos, ressaltam-se: o direito ao desenvolvimento, ao meio ambiente sadio, o direito à paz e o direito a autodeterminação dos povos, todos de interesse coletivos e apontam para a necessidade de superação - não no sentido de negação, mas sim no sentido de ir além, numa síntese superior - da estrutura tradicional do Estado moderno, mormente do conceito de soberania e da prerrogativa de monopólio de produção jurídica (BEDIN, op. cit., 2002, p. 131-132).

5 Narciso Leandro Xavier Baez e Vicente Barreto destacam como desafio inicial do tema dos direitos humanos, seu conceito e sua fundamentação, em particular, por três motivos. O primeiro, em razão de que os valores constantes no núcleo dessa categoria veiculam ideias da humanidade que se aplicam no tempo e no espaço. $\mathrm{O}$ segundo, devido à característica de direitos inatos e fundamentais, estendidos aos indivíduos simplesmente por serem seres humanos, o que leva parte da doutrina a os qualificarem como universais. O terceiro, por serem considerados necessários para que os indivíduos usufruam de uma vida digna, o que carrega diversos questionamentos acerca da concepção de vida digna. BAEZ, Narciso Leandro Xavier; BARRETO, Vicente (Org.). Direitos humanos em evolução. Joaçaba: Ed. da Unoesc, 2007, p. 14. 


\section{a fundamentação historicista; a proposta consensualista; e a fundamentação ética. ${ }^{6}$}

Sobre as propostas de fundamentação dos direitos humanos, pode-se dizer que existe uma divisão em duas correntes principais, os universalistas e os relativistas. No entanto, não interessa para o presente estudo a análise aprofundada sobre o universalismo, defendendo conteúdos morais em escala global, ou do relativismo, opondo-se a qualquer ideia de monismo cultural, mas sim observar a possibilidade de compatibilidade entre essas duas correntes, em busca de uma vida digna.

Para tanto, pretende-se verificar a relação entre a dignidade humana e direitos humanos, bem como se aquela representa um elemento nuclear para uma vida digna, especialmente em casos complexos, nos quais a atualidade e a velocidade dos fatos acabam sufocando o direito, que busca nos princípios e nas cláusulas gerais o ar necessário para tratar de conflitos desta espécie.

\footnotetext{
${ }^{6}$ Segundo Narciso Leandro Xavier Baez e Vicente Barreto: "a proposta jusnaturalista equipara os direitos humanos ao direito natural, concebido como um ordenamento universal, superior e anterior ao direito positivo, que é extraído da própria natureza humana. Juristas e filósofos como Grotius, Pufendorf, Hobbes, Locke e Kant defendiam a ideia da existência de direitos naturais, inatos ou originários, que precediam à formação do próprio pacto social e tinham sua origem na natureza humana", lição extraída de José Adércio Leite Sampaio. Para os dois autores, "os direitos humanos seriam, portanto, direitos naturais, inerentes aos seres humanos e, como anteriores a própria existência do Estado, deveriam ser por este reconhecidos e protegidos, não podendo ser suplantados pelo direito positivo, que lhes é hierarquicamente inferior. Além disso, sendo direitos naturais identificados como elementos comuns a todos os seres humanos, adquirem status universal e, por conseguinte, têm validade e fundamento em si mesmos, e independem de qualquer reconhecimento pelo direito positivo. Essa proposta sofreu várias críticas pelo fato da sua ingênua pretensão em atribuir ao direito natural uma superioridade jurídica ao direito positivo, quando, a bem da verdade, são categorias distintas e o único fundamento que poder-se-ia utilizar para essa abordagem seria o argumento ético, e não o jurídico. Além disso, a busca dessa categoria de direitos na natureza humana é uma tarefa obscura e turbulenta, visto que essa ideia é imprecisa e varia de acordo com o conjunto axiológico de quem a descreve e do momento histórico com que a análise é construída"; já "a fundamentação historicista dos direitos humanos sustenta que eles são direitos variáveis e relativos a cada contexto histórico, e de acordo com os desafios sociais de um dado momento. Seriam direitos desenvolvidos de acordo com a evolucão social, que buscariam atender às necessidades humanas estabelecidas de acordo com os valores construídos dentro de uma comunidade histórica", o que se extrai da leitura de Eusébio Fernandes. "Desse modo, os direitos humanos não são anteriores ou superiores à constituição da sociedade, mas sim o resultado da sua evolução e transformação. Essa abordagem tem o mérito de descrever, de maneira realista, a evolução e o desenvolvimento dos direitos humanos. Contudo, peca ao ignorar que certos direitos, como o direito à vida e a integridade física, são os mesmos desde o surgimento do homem, e deslocam-se no tempo e no espacco sem terem como fundamento o desenvolvimento social. Ao contrário, o progresso social culmina por reafirmar o caráter natural desses direitos. Por tais motivos, seria contraditório pretender defender a existencia de direitos humanos, fundamentais, que possam ser considerados relativos e variáveis em cada momento histórico"; "a proposta consensualista de fundamentação dos direitos humanos, por sua vez, é aquela que tem como base teorica as ideias de Norberto Bobbio, o qual defende que os valores de sustentação dos direitos fundamentais são obtidos por meio do consenso geral acerca da sua validade. Destaca que um embasamento absoluto para os direitos humanos é uma ilusão, e que a questão da fundamentação já foi superada desde a aprovação da Declaração Universal dos Direitos Humanos, pela Assembleia Geral das Nações Unidas, em 10 de dezembro de 1948, restando o problema, contudo, do desenvolvimento e formas para sua garantia". Conforme Javier Saldaña, "a posição defendida por Bobbio culmina por relativizar os direitos humanos, pois exige para o seu reconhecimento um acordo entre os membros de uma sociedade", reduzindo essa importante categoria a uma simples ideologia de um grupo, que pode sofrer variações no tempo, tornando-se vulnerável a diversas variáveis e circunstâncias sociais. Prova disso é o fato de que pode um grupo chegar ao consenso majoritário sobre valores contraditórios aos direitos humanos, reconhecendo, por exemplo, a prática da escravidão como algo permitido socialmente, e perpetrar ações tirânicas a partir desse consenso, diluindo a ideia de dignidade humana"; por fim, novamente valendo-se dos ensinamentos de Eusébio Fernandez, os autores referem que "a fundamentação ética dos direitos humanos parte do pressuposto de que o embasamento dos direitos humanos não pode ser jurídico, mas sim moral. Pressupõe a existência de uma moral básica, constituída em torno das exigências indispensáveis para garantir ao ser humano uma vida digna, de onde irradiam os valores formadores dos direitos humanos. $O$ papel do ordenamento jurídico não é o de criar direitos humanos, mas de reconhecê-los e transformá-los em normas jurídicas, para buscar a sua efetividade". BAEZ; BARRETO. Direitos humanos em evolução. p. 14-16.
} 
Para Joaquín Herrera Flores, os direitos humanos devem ser entendidos como:

os processos sociais, econômicos, políticos e culturais que, por um lado, configurem materialmente - através de processos de autoimposição de deveres e de construção de um sistema de garantias amplo, público e democrático - esse ato ético e político maduro e radical de criação de uma ordem nova; e, por outro, a matriz para a constituição de novas práticas sociais, de novas subjetividades antagonistas, revolucionárias e subversivas dessa ordem global oposta absolutamente ao conjunto imanente de valores - liberdade, fraternidade e igualdade - que tantas lutas e sacrifícios necessitaram para sua generalização.

$\mathrm{O}$ referido autor se mostra contrário a qualquer forma hegemônica (universal) de abordagem dos direitos humanos, alimentada, segundo ele, por influência de grandes organismos internacionais não democráticos (como FMI, $\mathrm{OMC}$ e BM), movidos pela força do capital e que acabam construindo um discurso ideológico acerca desses preceitos fundamentais, para, na realidade, suplantá-los com a lógica do mercado. Mas ressalta a importância de uma concepção material de dignidade humana, esclarecendo a importância dos movimentos antagônicos às tendências homogeneizadoras, bem como aponta o caminho para alcançar o referido objetivo, em que "os direitos humanos são o conjunto de processos de luta pela dignidade humana". 8

No entanto, o autor não despreza o diálogo cultural como forma de alcançar a dignidade humana e, nesse ponto, pode-se dizer que sua ideia vai ao encontro da hermenêutica diatópica de Boaventura Sousa Santos, segundo a qual "temos o direito a ser iguais quando a nossa diferença nos inferioriza; e temos o direito a ser diferentes quando a nossa igualdade nos descaracteriza. Daí a necessidade de uma igualdade que reconheça as diferenças e de uma diferença que não produza, alimente ou reproduza as desigualdades".?

No que tange à definição de dignidade humana e sua relação como os direitos humanos, Narciso Leandro Xavier Baez apresenta um método capaz de

\footnotetext{
7 FLORES, Joaquín Herrera. Teoria crítica dos direitos humanos: os direitos humanos como produtos culturais. Rio de Janeiro: Lumen Juris, 2009, p. 209.

${ }^{8}$ Ibidem, 2009, p. 213.

9 SANTOS, B. S. Introdução: para ampliar o cânone do reconhecimento, da diferença e da igualdade. In: RECONHECER para libertar: os caminhos do cosmopolitanismo multicultural. Rio de Janeiro: Civilização Brasileira, 2003 , p. 56.
} 
possibilitar uma proteção universal dos direitos humanos, sem acarretar desrespeito a fatores culturais, utilizando-se da dignidade humana como fator de coexistência ${ }^{10}$ entre as propostas universalista e relativista. Para melhor compreensão da questão, o autor propõe uma separação em dois níveis:

A dimensão básica da dignidade humana representa uma qualidade própria do indivíduo que vai demandar o respeito por sua vida, liberdade e integridade física e moral, materializando-se em um conjunto de direitos elementares que impedem a coisificação do ser humano. A dimensão cultural da dignidade da pessoa humana, por sua vez, representa as formas e as condições como a dignidade humana, em sua dimensão básica, é implementada por cada grupo social ao longo da história. Nesse nível de análise, abre-se espaço para as particularidades culturais e suas práticas, variáveis no tempo e no espaço, pois se busca uma compreensão ética das finalidades de cada grupo social, a fim de constituírem significados que tenham capacidade de ser entendidos interculturalmente. [...] entendido a dignidade humana, em sua dupla dimensão, e a sua posição ética intercultural como fundamento e objetivo dos direitos humanos, pode-se, então, afirmar que os direitos humanos (gênero) são um conjunto de valores éticos, positivados ou não, que têm por objetivo proteger e realizar a dignidade humana em suas dimensões: básica (protegendo os indivíduos contra qualquer forma de coisificação ou de redução do seu status como sujeitos de direitos) e cultural (protegendo a diversidade moral, representada pelas diferentes formas como cada sociedade implementa o nível básico da dignidade humana). ${ }^{11}$

O autor vê na ética, por sua capacidade de diálogo com as diversas morais, um mecanismo para conceituar e construir um parâmetro de identificação e interpretação dos direitos humanos. Assim, na análise de casos concretos, substituemse quaisquer aferições morais por análises objetivas e éticas dos fatos, passando-se a verificar tão somente se as circunstâncias avaliadas implicam ou não a redução dos indivíduos envolvidos a meros objetos, desprovidos de vontade.

\footnotetext{
${ }^{10}$ Assim, entende o autor que "um direito somente será humano quanto contiver em seu bojo valores éticos que representem formas de realização da dignidade humana". Destacando-se, que a dignidade humana representa um elemento de convergência entre várias declarações e tratados de direitos, estando presente, por exemplo: na Declaração Universal dos Direitos Humanos da ONU; na Declaração Americana de Direitos e Deveres do Homem; na Declaração Islâmica Universal dos Direitos Humanos; na Carta Africana dos Direitos Humanos e dos Povos; na Carta Árabe dos Direitos Humanos; na Carta dos Direitos Fundamentais da União Europeia. BAEZ, Narciso Leandro Xavier; CASSEL, Douglas (Org.). A realização e a proteção internacional dos direitos humanos fundamentais. Joaçaba: Ed. da Unoesc, 2011, p. 37-38.

${ }^{11}$ Ibidem, 2011, p. 35-37.
} 
Convém esclarecer, que uma vez positivados nos ordenamentos jurídicos dos Estados, os direitos humanos passam a ser denominados de direitos fundamentais, desse modo, revelando-se em importantes instrumentos para concretização de uma vida digna:

Pode-se afirmar que os direitos fundamentais são corolário dos direitos humanos, já que incorporam os valores éticos destes últimos ao ordenamento jurídico dos Estados, funcionando como instrumentos de efetividade e garantias da concretização de uma vida digna, aos indivíduos que estão sob a égide deste ente público. A importância dos direitos fundamentais está no fato de que a sua inserção nas constituições das diversas nações do mundo viabiliza a concretude dos direitos humanos, pois obrigam e vinculam os poderes públicos estatais, ao mesmo tempo em que fornecem aos indivíduos uma gama de ações judiciais para a defesa e realização dessa categoria de direitos. $^{12}$

Porém, o ordenamento jurídico nacional não se resume aos direitos e garantias expressos no texto constitucional, pois não são excluídos outros decorrentes do regime e dos princípios adotados pela Constituição, ou dos tratados internacionais em que a República do Brasil seja parte (artigo $5^{\circ}$, $2^{\circ}$, da Constituição Federal). Dessa forma, os tratados e convenções internacionais sobre direitos humanos que forem aprovados, em cada Casa do Congresso Nacional, em dois turnos, por três quintos dos votos dos respectivos membros, serão equivalentes às emendas constitucionais (artigo $5^{\circ}, \S 3^{\circ}$, da Constituição Federal).

No caso do Brasil, interessa para o presente estudo observar, com maior ênfase, a dignidade da pessoa humana, ou seja, no âmbito do sujeito individualmente considerado, e que se diferencia da dignidade humana, com características mais amplas ou universais, em uma escala que afeta a humanidade como um todo.

Definir dignidade da pessoa humana, por outro lado, não é tarefa fácil, tanto que já se afirmou que seria mais fácil desvendar e dizer o que a dignidade não é do que expressar o que ela é. ${ }^{13}$

No entanto, mostra-se oportuno consignar a definição proposta por Ingo Wolfgang Sarlet:

Temos por dignidade da pessoa humana a qualidade intrínseca e distintiva de cada ser humano que o faz merecedor do mesmo respeito e consideração por parte do Estado e da comu-

\footnotetext{
${ }^{12}$ BAEZ, Narciso Leandro Xavier; LEAL, Rogério Gesta; MEZZAROBA, Orides (Coord.). Dimensões materiais e eficácia dos direitos fundamentais. São Paulo: Modelo, 2010, p. 22.

${ }^{13}$ KUNIG apud SARLET, Ingo Wolfgang. Dignidade da pessoa humana e direitos fundamentais na Constituição Federal de 1988. Porto Alegre: Livraria do Advogado, 2001, p. 39.
} 
nidade, implicando, neste sentido, um complexo de direitos e deveres fundamentais que asseguram a pessoa tanto contra todo e qualquer ato de cunho degradante e desumano, como venham a lhe garantir as condições existenciais mínimas para uma vida saudável, além de propiciar e promover sua participação ativa e co-responsável nos destinos da própria existência e da vida em comunhão com os demais seres humanos. ${ }^{14}$

No plano jurídico nacional, a dignidade da pessoa humana está expressa no artigo $1^{\circ}$, inciso III, da Constituição Federal ${ }^{15}$ de 1988, como princípio fundamental e, por isso, constitui-se em norma basilar do regramento jurídico.

Essas breves considerações sobre a dignidade da pessoa humana demonstram uma das maiores conquistas do homem, surgida como forma de garantir essa condição inerente ao indivíduo, coibindo o constante desrespeito à vida, a usurpação do poder, as atrocidades sofridas pelas pessoas, além de toda forma de desrespeito às garantias individuais que o caráter subjetivo do referido preceito engloba.

Os processos evolutivos supracitados influenciaram o universo jurídico, deixando-se de privilegiar deveres para se declarar direitos, o que Norberto Bobbio chamou de Era dos Direitos, mas também afetaram de maneira significativa a identidade do sujeito e a relação desta com o corpo, o que traz implicações na forma de se tutelar o direito de ser o que se é.

A identidade antiga, em um ambiente que não prestigiava a subjetividade e a individualidade como vetores determinantes do ser, não tinha como assumir traços de diferenciação, sendo garantida por uma espécie de continuidade contínua, produzindo mais do mesmo sem a necessidade de apelar para o diferente. Nesse cenário, o sujeito é a encarnação da própria cidade e fora dela não existe. Já na modernidade, ganha relevo a autoconsciência do sujeito, a identidade assume uma dimensão variável, sendo que o "eu" é capaz de mudar e de ganhar novos contornos independentes dos elementos formais que alcançam, pois é na consciência que se processam as modificações que realmente importam para o indivíduo. Dessa forma, a identidade identifica ao diferenciar, reproduz unidade por processos de separação,

\footnotetext{
${ }^{14}$ SARLET, op. cit., 2001, p. 60.

${ }^{15}$ Art. $1^{\text {o }}$ A República Federativa do Brasil, formada pela união indissolúvel dos Estados e Municípios e do Distrito Federal, constitui-se em Estado Democrático de Direito e tem como fundamentos: III - a dignidade da pessoa humana;
} 
unifica dividindo e inclui excluindo. ${ }^{16}$

Para Doglas Cesar Lucas, "uma forma sofisticada de perceber a identidade como uma construção social é a sua relação com o corpo e no corpo", tendo em vista que o corpo carrega as características biológicas do sujeito, enquanto a identidade é a construção social de sua biografia. Ainda, o corpo fala e reclama por meio de biografia, pelos inúmeros "eus" que lhe dão sentido histórico, afetivo, sexual, etc. Além disso:

Tem sua forma própria de se manifestar. Requer normas de proteção que o reconheçam em sua totalidade. A igualdade moderna protege o corpo em sua condição de igualdade abstrata e universal. Liberdade de ir e vir; liberdade de pensar; liberdade de culto; e liberdade econômica são liberdades desse tipo, liberdades de traço universal, que, em certa medida, não se ocupam das diferenças como um valor positivo. Por isso, mesmo o gênero, a cor, a religiosidade, a sexualidade, verdadeiras manifestações dos diversos "eus" aprisionados no corpo biológico, foram praticamente desconsideradas, colocadas de lado, contrapostos, em nome de uma igualdade universal de tipo homogeneizadora. Nesse modelo moderno, a identidade nacional praticamente esgota o pertencimento, e o corpo e o "eu" relacionam-se de forma pouco complexa. O corpo, sua biologia, parece colonizar o "eu", a sua biografia, calando-o, negando sua visibilidade como valor positivo. ${ }^{17}$

Porém, a complexidade de poder ser o que se é, que caracteriza a identidade, pode ser entendida como um produto da modernidade, advinda das diversas transformações sociais e da relação do indivíduo com o dinamismo desse meio, passando de sujeito de deveres a sujeito de direitos.

Igualmente, esses acontecimentos marcam a libertação da identidade vista como uma identificação, algo imutável e quase estático, para uma forma natural e capaz de fazer alterações constantes em sua própria gramática de identificações, sendo que a biografia, com a qual se escreve a identidade também se transforma, passando a ser provisória e múltipla. A biologia do corpo e sua biografia se interrelacionam de modo dinâmico. ${ }^{18}$

Todavia, na linguagem jurídica, a identidade é reduzida a um modo de identificação, restando descaracterizada ao ser constituída normativamente pelo

\footnotetext{
${ }^{16}$ LUCAS, Doglas Cesar. A identidade como memória biográfica do corpo e sua proteção jurídica: itinerários de um paradoxo. Sequência, Florianópolis, n. 65, p. 125-154, dez. 2012, p. 129-131.

${ }^{17}$ Ibidem, 2012, p. 141-143.

${ }^{18}$ Ibidem, 2012, p. 143.
} 
direito, fazendo com que perca doses significativas de sua existência como liberdade de ser, o que revela um paradoxo: "somos aquilo que somos, aquilo que nos identifica, mas nem sempre temos o direito de ser o que somos em virtude de que a vivência de nossa identidade, como direito, está subordinada a condição de normatividade". Uma possível alternativa para a questão pode estar associada ao reconhecimento de uma racionalidade jurídica de tipo não "standartizador" e sectário, que seja capaz de apostar na humanidade comum como modelo universal de direitos humanos. ${ }^{19}$

Com essa breve referência à identidade, pretende-se, agora, alimentar a discussão com a riqueza dos fatos sociais, que informam e de onde emerge o direito, trazendo à tona a problemática dos transexuais e da reconstrução da biologia do corpo, que a princípio, não está na esfera de disposição do sujeito.

Assim, o problema da identidade que quer redesenhar o corpo, redefinido aquilo que biologicamente foi atribuído ao sujeito, especialmente quanto à sua sexualidade e gênero, será o próximo tema abordado, o que permitirá, em momento posterior, examinar o caminho à vida digna dessas pessoas e a importância da dignidade da pessoa humana para alcançar este fim.

\section{TRANSEXUALISMO E TRANSGENITALIZAÇÃO}

O transexualismo é reconhecido como uma patologia ${ }^{20}$ em que os inconformados com sua sexualidade buscam imperativamente o ajuste sexual, mostrando-se inócuo o tratamento psicoterápico.

Dessa forma, surge a necessidade de adequar o sexo morfológico com o psicológico eliminando, assim, a causa de repulsa que leva à automutilação e ao suicídio. Segundo Roberto Farina:

O transexualismo consiste em uma pseudo-síndrome psiquiátrica, profundamente dramática e desconcertante, na qual o indivíduo se identifica com o gênero oposto. Constitui um dos mais controvertidos dilemas da medicina moderna, em cujo recinto poucos médicos ousam adentrar. Trata-se de manifes-

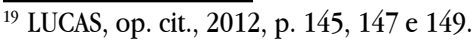

${ }^{20}$ CID-10 (Décima Revisão da Classificação Internacional das Doenças) [...] F64 Transtornos da identidade sexual. Item F64.0 Transexualismo - Trata-se de um desejo de viver e ser aceito enquanto pessoa do sexo oposto. Este desejo se acompanha em geral de um sentimento de mal estar ou de inadaptação por referência a seu próprio sexo anatômico e do desejo de submeter-se a uma intervenção cirúrgica ou a um tratamento hormonal a fim de tornar seu corpo tão conforme quanto possível ao sexo desejado. [...].
} 
tação extrema de inversão psicossexual, em que o indivíduo nega o seu sexo biológico e exige a operação de reajustamento sexual a fim de poder assumir a identidade do seu verdadeiro gênero, que não condiz com seu sexo anatômico. ${ }^{21}$

Todavia, a problemática não se restringe ao preconceito e à falta de solidariedade enfrentada pelos transexuais. A busca da dignidade e da inserção social perpassa, necessariamente, pela redesignação sexual. Este caminho, árduo e complexo, mostra-se como a única alternativa realmente eficaz para os almejados objetivos.

Destarte, devido à complexidade da intervenção cirúrgica, há de se analisar a sua real necessidade. Por isso, apenas os transexuais primários são indicados para esse procedimento, ou seja, aqueles que rejeitam veementemente a sua genitália e que tentam escondê-la a qualquer custo, inclusive, acabam conseguindo atrofiá-la. Para essas pessoas, os seus órgãos genitais possuem mera função mictória.

"Essas características, aliadas ao histórico comportamental do indivíduo desde a infância, determinam o transexual real". ${ }^{22}$ Esse diagnóstico complexo, deve ser realizado dentro de padrões rígidos para a real constatação da patologia.

Para o transexual masculino, seu órgão sexual não tem valor algum, sendo rejeitado incessantemente, pois se sente uma mulher. Nesses casos, "a cirurgia de redesignação sexual consistirá basicamente de amputação do falo e abertura do seio urogenital, com exteriorização do meato uretral e do intróito vaginal, seguida de plástica do vestíbulo". 23

Tereza Rodrigues Vieira traz a lição de Harry Benjamin, o qual descreve que na maioria dos casos, "a operação consiste em três fases principais, a castração, a amputação do pênis e a cirurgia plástica, esta visando a criar uma vagina artificial, além dos genitais externos que se assemelhem aos de uma mulher" ${ }^{24}$

Como referido, a adequação do sexo psicológico ao físico é bastante abstrusa para aqueles que se consideram mulheres aprisionadas em corpos de homens. Quando o sexo atribuído é o masculino, o caminho percorrido se mostra muito mais tormentoso quanto ao acima referido. Para tanto:

O fechamento da abertura vaginal se dá e é construído um

\footnotetext{
${ }^{21}$ FARINA, Roberto. Transexualismo: do homem à mulher normal através dos estados de intersexualidade e das parafilias. São Paulo: Novalunar, 1982, p. 117.

${ }^{22}$ FARINA apud CHAVES, Antonio. Direito à vida e ao próprio corpo: intersexualidade, transexualidade, transplante. 2. ed. São Paulo: Revista dos Tribunais, 1994, p. 114.

${ }^{23}$ LODOVICI apud CHAVES, op. cit., 1994, p. 144-145.

${ }^{24}$ VIEIRA, Tereza Rodrigues. Mudança de sexo: aspectos médicos, psicológicos e jurídicos. São Paulo: Livraria Santos, 1996, p. 98.
} 
neopênis bem como testículos de silicone com total insensibilidade sexual, uma vez que o clitóris é eliminado. Tais artifícios serão plasticamente semelhantes aos de uma genitália normal, mas, além de uma constante semi-ereção, onde também não há elasticidade, há o problema de insensibilidade. ${ }^{25}$

O Ministério da Saúde passou a reconhecer o direito dos transexuais ao atendimento no âmbito do Sistema Único de Saúde, editando a Portaria 1.707/08, que institui no âmbito do SUS o processo transexualizador, objetivando o atendimento de transexuais e a preservação da dignidade dessas pessoas. ${ }^{26}$

Ocorre que, com procedimento cirúrgico de transgenitalização, surge para o transexual a necessidade de alterações nos seus registros, de forma que possa ser inserido na sociedade em que vive, livre de discriminações em função do seu antigo prenome e sexo.

Para tanto, além da transformação corporal, mostra-se necessária uma transformação jurídica, sendo a análise dessa possibilidade o principal objetivo do presente estudo. Nesse ponto, reside o grande problema acerca da possibilidade ou inviabilidade da adequação social do transexual redesignado, uma vez que a lei silencia a esse respeito e, por outro lado, as informações constantes nos Registros Públicos são revestidas de uma imutabilidade relativa.

\section{BASES JURÍdICAS PARA ALTERAÇÃO DO PRENOME E SEXO DOS TRANSE- XUAIS}

Em que pese o ordenamento jurídico pátrio ser silente em relação à matéria

\footnotetext{
${ }^{25}$ SUTTER apud CHAVES, op. cit., 1994, p. 147.

${ }^{26}$ Considerando que a orientação sexual e a identidade de gênero são fatores reconhecidos pelo Ministério da Saúde como determinantes e condicionantes da situação de saúde, não apenas por implicarem práticas sexuais e sociais específicas, mas também por expor a população GLBTT (Gays, Lésbicas, Bissexuais, Travestis e Transexuais) a agravos decorrentes do estigma, dos processos discriminatórios e de exclusão que violam seus direitos humanos, dentre os quais os direitos à saúde, à dignidade, à não discriminação, à autonomia e ao livre desenvolvimento da personalidade; [...] Art. $2^{\circ}$ - Estabelecer que sejam organizadas e implantadas, de forma articulada entre o Ministério da Saúde, as Secretarias de Saúde dos Estados, dos Municípios e do Distrito Federal, as ações para o Processo Transexualizador no âmbito do SUS, permitindo: I - a integralidade da atenção, não restringindo nem centralizando a meta terapêutica no procedimento cirúrgico de transgenitalização e de demais intervenções somáticas aparentes ou inaparentes; II - a humanização da atenção, promovendo um atendimento livre de discriminação, inclusive pela sensibilização dos trabalhadores e dos demais usuários do estabelecimento de saúde para o respeito às diferenças e à dignidade humana; III - a fomentação, a coordenação e a execução de projetos estratégicos que visem ao estudo de eficácia, efetividade, custo/benefício e qualidade do processo transexualizador; e IV - a capacitação, a manutenção e a educação permanente das equipes de saúde em todo o âmbito da atenção, enfocando a promoção da saúde, da primária à quaternária, e interessando os pólos de educação permanente em saúde.
} 
dos transexuais, caberá ao magistrado, no caso concreto, fazer uso da analogia, dos costumes e dos princípios gerais do direito, consoante o artigo $4^{\circ}$ da Lei de Introdução às Normas do Direito Brasileiro. ${ }^{27}$

Destaque-se, por oportuno, que na aplicação da lei, o juiz atenderá aos fins sociais a que ela se dirige e às exigências do bem comum, conforme preceitua $o$ artigo $5^{\circ}$ do mesmo diploma legal. ${ }^{28}$

A questão não é simples, para se comprovar essa assertiva, basta elencar alguns reflexos jurídicos da alteração de prenome e sexo do transexual: Como fica o matrimônio com outro indivíduo do seu antigo estado sexual? O desconhecimento do parceiro ou parceira em relação à condição anterior à transgenitalização e da adequação social do transexual daria ensejo à anulação do casamento ${ }^{29}$ Quando preso, aonde essa pessoa irá cumprir pena? Como ficaria a aplicabilidade da Lei Maria da Penha ${ }^{30}$ para esse indivíduo? No caso dos esportes, em qual modalidade ele se enquadraria, na do antigo ou na do novo sexo? Os filhos desse sujeito teriam dois pais ou duas mães? Além disso, uma diversidade de hipóteses será revelada pela riqueza do quotidiano.

Embora controvertido, o tema merece uma tutela jurisdicional, que garanta a dignidade dessas pessoas, evitando-se processos discriminatórios violadores de direitos humanos, exigindo-se um exercício hermenêutico que contemple a complexidade e amplitude da problemática dos transexuais.

Nesse contexto, salienta-se que a hermenêutica não é um método, mas um modo-de-ser-no-mundo do intérprete que vai determinar o sentido, uma maneira como o ser humano se abre para o mundo na compreensão, não havendo uma fórmula para se estar no mundo e para se constituir em sua historicidade e temporalidade. Assim, não é possível acessar a Constituição por fórmulas e métodos, já que é a sua relação com o mundo que conforma seus significados, sentidos, interpretação. Ainda, a Constituição é um projeto que se projeta e se executa permanentemente, não se configurando em objeto aprisionável a ser conhecido arbitrariamente pelo

\footnotetext{
${ }^{27}$ Art. $4^{0}-$ Quando a lei for omissa, o juiz decidirá o caso de acordo com a analogia, os costumes e os princípios gerais de direito.

${ }^{28}$ Art. $5^{\circ}-\mathrm{Na}$ aplicação da lei, o juiz atenderá aos fins sociais a que ela se dirige e às exigências do bem comum.

${ }^{29}$ Nesse sentido, poder-se-ia questionar sobre a aplicabilidade dos artigos 1.556 e 1.557 do Código Civil Brasileiro: 1.556 - O casamento pode ser anulado por vício da vontade, se houve por parte de um dos nubentes, ao consentir, erro essencial quanto à pessoa do outro; art. 1.557 - Considera-se erro essencial sobre a pessoa do outro cônjuge: I - o que diz respeito à sua identidade, sua honra e boa fama, sendo esse erro tal que o seu conhecimento ulterior torne insuportável a vida em comum ao cônjuge enganado; II - a ignorância de crime, anterior ao casamento, que, por sua natureza, torne insuportável a vida conjugal; III - a ignorância, anterior ao casamento, de defeito físico irremediável, ou de moléstia grave e transmissível, pelo contágio ou herança, capaz de pôr em risco a saúde do outro cônjuge ou de sua descendência; IV - a ignorância, anterior ao casamento, de doença mental grave que, por sua natureza, torne insuportável a vida em comum ao cônjuge enganado.

${ }^{30}$ Lei 11.340 , de 07 de agosto de 2006.
} 
jurista, mas como um acontecer que é (des)ocultado pela maneira de os juristas pré-compreenderem o papel da Constituição para a realização de um projeto de comunidade..$^{31}$

Com efeito, cabe uma análise dos dispositivos legais existentes dentro do quadro normativo atual, objetivando, com isso, delinear um caminho à luz da Constituição Federal, por meio do qual se conclua pela possibilidade ou inviabilidade da adequação social almejada pelo transexual redesignado.

A partir do momento em que o homem começou a expressar verbalmente seus pensamentos passou, também, a denominar as coisas e seus iguais. O nome compõe um dos direitos da personalidade, assim como à privacidade, à integridade física, à imagem, à honra, além de outros, pois a composição da personalidade não se limita a um rol exaustivo de direitos.

No Brasil, esses direitos encontram guarida na Constituição Federal ${ }^{32}$, como pode ser observado no artigo $5^{\circ}$, incisos, V, X, XXVIII, LXXVI, alínea a, seguindo uma tendência protetiva conferida à personalidade. Nessa esteira, a Lei 10.406/02, Código Civil Brasileiro, conferiu tratamento especial ao assunto aventando a matéria no Capítulo II, artigos 11 a 21. Esses dispositivos devem orientar a doutrina e o julgador.

Dessa maneira, esses preceitos visam a garantir a dignidade da pessoa humana, guardando relação com os direitos humanos e com o cenário acima delineado, segundo Maria Helena Diniz:

Feita a cirurgia de redesignação sexual ou de mudança de sexo num transexual, o direito, a sociedade e o Poder Judiciário poderiam proibir que leve vida feliz e normal? Poder-lhe-iam negar efeitos jurídicos oriundos de sua nova condição sexual? Se com o término da Segunda Guerra Mundial passou-se a proteger com intensidade maior o direito da personalidade, em virtude da Declaração Universal dos Direitos do Homem e Liberdades Fundamentais de 1950, se direito da personalidade é o direito à conservação, invulnerabilidade, dignidade e

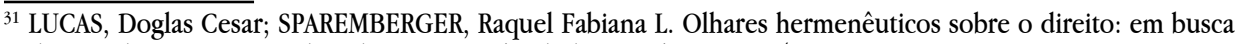
de sentido para os caminhos do jursita. Ijuí: Ed. da Unijuí, 2007, p. 48 e 58.

${ }^{32}$ Art. $5^{\circ}[\ldots] \mathrm{V}$ - é assegurado o direito de resposta, proporcional ao agravo, além da indenização por dano material, moral ou a imagem. [...] X - são invioláveis a intimidade, a vida privada, a honra e a imagem das pessoas, assegurado o direito a indenização pelo dano material ou moral decorrente de sua violação. [...] XXVIII - são assegurados, nos termos da Lei: a) a proteção às participações individuais em obras coletivas e à reprodução da imagem e voz humanas, inclusive nas atividades desportivas; b) o direito de fiscalização do aproveitamento econômico das obras que criarem ou de que participarem aos criadores, aos interpretes e às respectivas representações sindicais e associativas. [...] LXXVI - são gratuitos para os reconhecidamente pobres, na forma da lei: a) o registro civil de nascimento [...]. 
reconhecimento da livre atuação da personalidade em todas as suas direções, gerando um dever jurídico de abstenção para todos os membros da coletividade, não se deveriam admitir direitos ao transexual operado? Não deveria a lei, evitando discriminação, facilitar seu direito à identidade sexual? ${ }^{33}$

Portanto, os direitos da personalidade, em especial o direito ao nome, direito à privacidade, sobre o próprio corpo, à imagem, à honra, bem como o direito à identidade sexual, este último, tanto como um direito autônomo ou como integrante da personalidade, representam a proteção dos valores inerentes à pessoa, em seu aspecto físico, moral e intelectual.

Nesse sentir, os direitos de personalidade englobam "os direitos de estado (por ex.: direito de cidadania), os diretos sobre a própria pessoa (direito à vida, à integridade moral e física, direito à privacidade), os direitos distintivos da personalidade (direito a identidade pessoal, direito à informática) e muitos dos direitos de liberdade (liberdade de expressão)" ${ }^{34}$

Os direitos da personalidade, por si só, teriam força para embasar a pretensão dos transexuais, seja quanto à realização da cirurgia, seja com relação ao ajuste no registro civil, pois se tratam de direitos fundamentais, ou seja, desdobramentos lógicos do princípio da dignidade da pessoa humana, que objetivam a concretização deste fundamento constitucional. Segundo José Afonso da Silva,

A Constituição declara invioláveis a intimidade, a vida privada, a honra e a imagem. Portanto, erigiu, expressamente, esses valores humanos à condição de direitos individuais, mas não o fez constar do caput do artigo. Por isso, estamos considerando-o um direito conexo ao da vida. Assim, ele figura no caput como reflexo ou manifestação deste..$^{35}$

Não obstante, some-se a tudo isso, que na condição de direitos fundamentais, gozam de aplicabilidade imediata, não dependendo de regulamentação infraconstitucional (artigo $5^{\circ}, \S 1^{\circ}$, Constituição Federal).

Igualmente importante, são os incisos I, II e IV do artigo $3^{\circ}$ da Constituição

\footnotetext{
${ }^{33}$ DINIZ, Maria Helena. O estudo atual do biodireito. São Paulo: Saraiva, 2001, p. 235.

${ }^{34}$ CANOTILHO, José Joaquim Gomes. Direito Constitucional e teoria da constituição. 7. ed. Coimbra: Almedina, 2003 , p. 396.

${ }^{35}$ SILVA, José Afonso da. Curso de direito constitucional positivo. 23. ed. rev. e atual. nos termos da reforma constitucional. São Paulo: Malheiros, 2004, p. 204-205.
} 
Federal $^{36}$, que constituem objetivos fundamentais da República Federativa do Brasil, bem como o artigo $5^{\circ}$, caput, da Carta Constituciona ${ }^{37}$, que reza pela inviolabilidade, dentre outros direitos, à vida, à liberdade e à igualdade.

Então, tem-se por objetivos fundamentais os princípios que devem nortear todo o aparato constitucional e infraconstitucional. O objetivo de uma sociedade livre, justa e solidária advém da reunião desses elementos no momento de interpretação da norma constitucional. Isso proporciona a liberdade de agir do transexual pela direção do seu bem-estar, dentro do justo, uma vez afastada a prática ilícita ou ilegal e respeitado o direito de terceiros. Ainda, com o respaldo dos seus semelhantes solidários à causa e não com imposição de obstáculos.

A erradicação da pobreza e da marginalização, bem como da redução das desigualdades sociais e regionais, são questões que estão ligadas ao dever do Estado de promover a justiça social. Nesse contexto, faz-se necessário refletir a condição do transexual operado que aguarda o ajuste do prenome e sexo no registro civil:

Manter-se um ser amorfo, por um lado, mulher, psíquica e anatomicamente reajustada, e por outro lado homem, juridicamente, em nada contribuiria para a preservação da ordem social e da moral, parecendo-nos muito pelo contrário um fator de instabilidade para todos aqueles que com ela contatassem, quer nas relações pessoais, sociais e profissionais, além de constituir solução amarga, destrutiva, incompatível com a vida. ${ }^{38}$

Nesse aspecto, o transexual vive às margens da sociedade, uma vez que para integrá-la, de acordo com a sua nova condição, dependerá da concretização do ajuste do prenome e do sexo no registro civil, possibilitando, enfim, a tranquilidade em ser o que sempre foi. Assim, o referido dispositivo constitui uma forte base para pretensão desses indivíduos, onerando o Estado à prestação de atividades que visem ao pleno desenvolvimento da personalidade humana, uma vez que se trata de um meio hábil para atingir o objetivo fundamental almejado.

No que tange à promoção do bem de todos, sem preconceitos de origem,

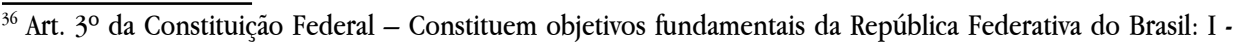
construir uma sociedade livre, justa e solidária; [...] III - erradicar a pobreza e a marginalização e reduzir as desigualdades sociais e regionais e IV - promover o bem de todos, sem preconceitos de origem, raça, sexo, cor, idade e quaisquer outras formas de discriminação.

${ }^{37}$ Art. $5^{\circ}$ da Constituição Federal - Todos são iguais perante a lei, sem distinção de qualquer natureza, garantindo-se aos brasileiros e aos estrangeiros residentes no País a inviolabilidade do direito à vida, à liberdade, à igualdade, à segurança e à propriedade, nos termos seguintes [...].

${ }^{38}$ MOUSNIER apud CHAVES, op. cit., 1994, p. 160.
} 
raça, sexo, cor, idade e quaisquer outras formas de discriminação, destaca-se:

Que se entende bem de todos, conforme determina o art. $3^{\circ}$ da Constituição Federal? Certamente se está a falar de felicidade. [...] A felicidade é um estado de ventura, que atende à multiplicidade de valores e anseios do ser humano, individualmente considerado. Não se pode falar de felicidade geral, mas da felicidade de cada ser humano. A felicidade geral é a soma das felicidades individuais atendidas. Portanto, a busca do fim social do Estado deve, obrigatoriamente, fundar-se na busca da felicidade. Os anseios individuais, a captação das mudanças sociais pelo Estado, $\mathrm{o}$ atendimento às necessidades básicas do ser humano estão, certamente, entre os fins objetivados pelo Estado e reconhecidos pelo constituinte de $1988 .{ }^{39}$

Conforme a admirável lição, a felicidade se mostra como algo a ser respeitado e buscado, considerando-se, para tanto, a individualidade de cada pessoa e se respeitando o direito alheio. Destarte, a transgenitalização se mostra como um caminho eficaz, talvez único, para a síndrome do transexualismo. Assim, o procedimento cirúrgico se realiza em prol da saúde e da felicidade do transexual, sem afetar direito alheio, estando em consonância com os objetivos da República.

Com relação ao direito à vida, não se quer, aqui, esgotar o assunto, mas sim, expor a amplitude de reflexões advindas do tema, demonstrando a sua importância. Para tanto, giza-se algumas ponderações mencionadas por Antônio Chaves:

Quem poderá definir essa pulsação misteriosa, própria aos organismos animais e vegetais, que sopita inadvertida nas sementes de trigo encontradas nos sarcófagos de faraós egípcios e que germina milagrosamente depois de dois milênios de escuridão, que se oculta na gema de uma roseira que mãos habilidosas transplantam de um para outro caule, que lateja, irrompe e transborda na inflorescência de milhões de espermatozóides que iniciam sua corrida frenética à procura de um único óvulo, a cada encontro amoroso ${ }^{40}$

Em que pese à amplitude de uma possível definição de vida ${ }^{41}$, interessa para o presente estudo, no campo do direito, relacioná-la com a problemática dos

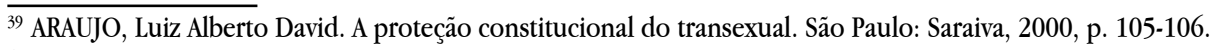

${ }^{40}$ CHAVES, op. cit., 1994, p. 13.

${ }^{41}$ Para José Afonso da Silva: "A vida humana não é apenas um conjunto de elementos materiais. Integram-na, outrossim, valores imateriais, como os morais. [...] A moral individual sintetiza a honra da pessoa, o bom nome, a boa fama, a reputação que integram a vida humana como dimensão imaterial. Ela e seus componentes são atributos sem os quais a pessoa fica reduzida a uma condição animal de pequena significação. Daí por que o respeito à integridade moral do indivíduo assume feição de direito fundamental". SILVA, op. cit., 2004, p. 200.
} 
transexuais, pelo que se depreende não ser um simples processo vital, pois a sua plena aplicabilidade na condição de um direito fundamental deve contemplar a observância de outros mandamentos fundamentais.

Por derradeiro, cabe salientar a relação do direito à vida com outros direitos imateriais, sendo que a sua amplitude pode conferir aos transexuais tanto o direito à transgenitalização quanto à adequação social no registro civil, pois considerar a vida como um simples processo vital seria restringir o seu alcance aquém da sua proteção constitucional.

Quanto à liberdade, caracteriza-se pelo ato do indivíduo guiar-se conforme sua vontade, sem influência externa e, claro, sem acarretar prejuízos para terceiros. Para José Afonso da Silva, "a liberdade consiste na possibilidade de coordenação dos meios necessários à realização da felicidade pessoal”. ${ }^{42}$

Então, aquele transexual que vive aprisionado em seu próprio corpo, ou, ainda, mesmo depois da redesignação, quando não consegue o ajuste do prenome e sexo no registro civil, tem limitado o seu direito à liberdade e à felicidade. Por essa razão, o direito à liberdade compõe mais uma das garantias a ser invocada para a satisfação da pretensão dos transexuais.

Quanto ao direito à igualdade, é um dos objetivos perseguidos pelos direitos sociais, ainda, protege o cidadão da má utilização que por ventura seja feita da ordem jurídica. Com efeito, pela intervenção estatal, busca-se a proteção do mais fraco, ou seja, constitui-se em um tratamento desigual aos desiguais visando à igualdade.

Ao impedir o transexual de realizar a cirurgia de adequação sexual ou tolher o seu direito de regularização de estado, estaria impedindo-se o seu direito à vida, à liberdade e à igualdade. No primeiro caso, pela limitação ao direito à saúde. No segundo, impedindo a busca da felicidade. Por fim, representaria a própria inversão do mandamento constitucional, uma vez que o direito à igualdade condiciona os demais. Assim, negar o direito aos transexuais seria desprezar o lado mais fraco da relação, quando o mandamento constitucional justamente prescreve o contrário.

De outra parte, a síndrome do transexualismo se caracteriza como uma patologia, guardando relação com o direito à saúde, classificado como um dos mais importantes direitos humanos, encontrando ampla previsão em tratados e convenções internacionais, como o artigo 25 da Declaração Universal dos Direitos

\footnotetext{
$\overline{42}$ SILVA, op. cit., 2004, p. 232.
} 
Humanos. ${ }^{43}$

Luigi Ferrajoli concebe a saúde como um direito corolário ao direito à vida e tipicamente molecular, que pode ser visto sob dois enfoques, negativo e positivo:

[...] el derecho a la salud se configura como un derecho tipicamente molecular. Que, de una parte, incluye un derecho negativo de inmunidad garantizado por la prohibición de lesiones: que el aire y el agua no sean contaminados, que no se comercialicen comidas adulteradas, dicho brevemente, que no se ocasionen daños a la salud; y, de outra, un derecho positivo, tipicamente social a la erogación de prestaciones sanitárias. En este segundo sentido, el derecho positivo a la salud, dada su universalidad, sólo podrá ser garantizado a todos si sus garantías positivas se encomiendam a la esfera pública. Pues, em efecto, si como derecho negativo es un derecho absoluto, es decir, erga omnes, como derecho positivo es prevalentemente un derecho relativo al que corresponden obligaciones de prestación a cargo de las instituciones públicas. ${ }^{44}$

Todavia, considerando-se o ordenamento pátrio como objeto de estudo, há de se analisá-lo como um direito fundamental, tanto por força do disposto no artigo $5^{\circ}$, parágrafos $2^{\circ}$ e $3^{\circ}$, da Constituição Federal ${ }^{45}$, quanto pelas demais positivações na esfera constitucional e infraconstitucional.

Nesse contexto, o artigo $6^{\circ}$ da Lei Maior ${ }^{46}$, inserido no capítulo II, Dos Diretos Sociais, o qual integra o título II, denominado Dos Direitos e Garantias Fundamentais, elenca a saúde como um direito social, pelo que se entende tratar de um direito fundamental social, apresenta-se como um instrumento hábil e a altura da relevância dos anseios dos transexuais.

A uma, porque os direitos sociais e fundamentais têm aplicabilidade imediata (artigo $5^{\circ}, \S 1^{\circ}$, da Constituição Federal), além de não estarem submetidos a instâncias administrativas, tão pouco dependem de lei para sua efetivação. A duas,

\footnotetext{
${ }_{43}$ Toda pessoa tem direito a um padrão de vida capaz de assegurar a si e a sua família saúde e bem estar, inclusive alimentação, vestuário, habitação, cuidados médicos e os serviços sociais indispensáveis, o direito à segurança, em caso de desemprego, doença, invalidez, viuvez, velhice ou outros casos de perda dos meios de subsistência em circunstâncias fora do controle.

${ }^{44}$ FERRAJOLI, Luigi. Principia iuris. Teoría del derecho y de la democracia. 2. Teoría de la democracia. Tradução Perfecto Andrés Ibáñez, Carlos Bayón, Maria Gascón, Luis Prietro Sanchís y Alfonso Ruiz Miguel. Madrid: Trota, 2011, p. 394-395.

${ }^{45}$ Artigo $5^{\circ}[\ldots]$ Parágrafo $2^{\circ}$ - Os direitos e garantias expressos nesta Constituição não excluem outros decorrentes do regime e dos princípios por ela adotados, ou dos tratados internacionais em que a República Federativa do Brasil seja parte. Parágrafo $3^{\circ}$ : Os tratados e convenções internacionais sobre direitos humanos que forem aprovados, em cada Casa do Congresso Nacional, em dois turnos, por três quintos dos votos dos respectivos membros, serão equivalentes às emendas constitucionais.

${ }^{46}$ Art. $6^{\circ}$ São direitos sociais a educação, a saúde, o trabalho, a moradia, o lazer, a segurança, a previdência social, a proteção à maternidade e à infância, a assistência aos desamparados, na forma desta Constituição.
} 
porque caberá ao Estado garantir e promover esses direitos ${ }^{47}$, assim, o transexual terá direito ao tratamento adequado à sua patologia. Por fim, salienta-se que, o pósoperatório, desprovido do ajuste de estado no registro civil, poderá implicar em nova patologia psíquica, ante a impossibilidade de inserção social do transexual redesignado, o que lhe deixaria na mesma situação anterior à cirurgia, ou seja, às margens da sociedade e, ainda, persistiria o dilema do equilíbrio corpo-mente.

Todo aparato normativo delineado até o momento leva ao entendimento que, na verdade, busca-se a dignidade da pessoa humana. Nesse particular, Ingo Wolfgang Sarlet esclarece que:

Onde não houver respeito pela vida e pela integridade física e moral do ser humano, onde as condições mínimas para uma existência digna não forem asseguradas, onde não houver limitação do poder, em fim, onde a liberdade e a autonomia, a igualdade (em direitos e obrigações) e os direitos fundamentais não forem reconhecidos e minimamente assegurados, não haverá espaço para a dignidade da pessoa humana e esta (a pessoa), por sua vez, poderá não passar de mero objeto de arbítrio e injustiças. ${ }^{48}$

Assim, como parece anunciar o preâmbulo da Constituição ${ }^{49}$, a essência da pretensão dos transexuais, assim como a de qualquer Estado Democrático de Direito, será a dignidade da pessoa humana, que engloba uma vida digna e com qualidade, por meio do bem-estar físico, mental e social.

Com base no que foi exposto, trilhando o caminho desenhado à luz da Lei Maior, caberá atacar o tema principal, a alteração do prenome e do sexo dos transexuais no registro civil após a transgenitalização.

\section{ADEQUAÇÃO SOCIAL DOS TRANSEXUAIS}

Partindo da ideia de que o sexo não deve ser analisado apenas do prisma

\footnotetext{
$\overline{47}$ Art. 196. A saúde é direito de todos e dever do Estado, garantido mediante políticas sociais e econômicas que visem à redução do risco de doença e de outros agravos e ao acesso universal e igualitário às ações e serviços para sua promoção, proteção e recuperação. (Constituição Federal).

${ }^{48}$ SARLET, op. cit., 2001, p. 59.

${ }^{49}$ Nós, representantes do povo brasileiro, reunidos em Assembléia Nacional Constituinte para instituir um Estado Democrático, destinado a assegurar o exercício dos direitos sociais e individuais, a liberdade, a segurança, o bem-estar, o desenvolvimento, a igualdade e a justiça como valores supremos de uma sociedade fraterna, pluralista e sem preconceitos, fundada na harmonia social e comprometida, na ordem interna e internacional, com a solução pacífica das controvérsias, promulgamos, sob a proteção de Deus, a seguinte Constituição da República Federativa do Brasil.
} 
fisiológico, ou seja, geneticamente determinado e, por natureza imutável, mas sim, de forma ampla, considerando-se, para tanto, os elementos genéticos, morfológico, endócrino, psíquico e civil, além do conhecimento científico acerca da problemática da transexualidade, será possível se desvencilhar do preconceito, fruto do desconhecimento.

Como mencionado, a síndrome do transexualismo constitui-se em uma patologia, na qual o indivíduo possui convicção inalterável de pertencer ao sexo oposto, repudiando seus órgãos sexuais. Essa convicção e o conflito veemente como seus órgãos sexuais apenas se resolve com a transgenitalização.

Ocorre que, após o reajuste sexual, inicia-se outra etapa a ser transposta pelo transexual, ou seja, a adequação social por meio da alteração do seu prenome e do seu sexo no registro civil. Para tanto, o transexual deverá recorrer ao judiciário que decidirá quanto à viabilidade ou não dessa adequação.

Contudo, os Registros Públicos revestem-se de publicidade e notoriedade em relação aos atos registrados, pois o artigo $1^{\circ}$ da Lei $6.015 / 73^{50}$ refere que seus serviços visam à autenticidade e eficácia dos atos jurídicos. A referida lei elenca em seu artigo $1^{\mathrm{o}}$, parágrafo $1^{\mathrm{o}}$, inciso $\mathrm{I}^{51}$, o registro civil das pessoas naturais como um desses serviços, com finalidade de autenticidade, segurança e eficácia.

Assim, em conformidade com o artigo $9^{\circ}$ do Código Civil ${ }^{52}$, devem constar nos Registros Públicos, em especial, no supracitado, os nascimentos, casamentos, óbitos, emancipações, interdições, sentenças de ausência e morte presumida.

Portanto, indiscutivelmente, revestem-se de notoriedade os referidos serviços, inclusive, denota-se o interesse individual e público das situações vinculadas à condição da pessoa na sociedade e noticiadas nos Registros.

Os Registros Públicos são dotados de imutabilidade relativa, pois há casos em que se torna possível a alteração de suas informações, como acontece no registro civil das pessoas naturais, para alteração do prenome e nome, não só dos casos previstos em lei, mas também do prenome dos transexuais.

Em relação ao caso específico dos transexuais, a doutrina e a jurisprudência

\footnotetext{
${ }^{50}$ Art. $1^{\mathrm{o}}$ - Os serviços concernentes aos Registros Públicos, estabelecidos pela legislação civil para autenticidade, segurança e eficácia dos atos jurídicos, ficam sujeitos ao regime estabelecido nesta Lei.

${ }^{51}$ Art. $1^{0}[\ldots]$ parágrafo $1^{\circ}$ - Os Registros referidos neste artigo são os seguintes: I - o registro civil de pessoas naturais;

${ }^{52}$ Art. $9^{\circ}$ - Serão registrados em registro público: I - os nascimentos, casamentos e óbitos; II - a emancipação por outorga dos pais ou por sentença do juiz; III - a interdição por incapacidade absoluta ou relativa; IV - a sentença declaratória de ausência e de morte presumida.
} 
firmaram o entendimento no sentido de que os artigos $55^{53}$ e $58^{54}$ da Lei de Registros Públicos representam um meio de atingir a finalidade social da norma, considerando a omissão de lei específica autorizando a adequação social do transexual operado.

Ocorre que, após a cirurgia, a manutenção do prenome dissociado à imagem do transexual só causará situação ridícula e vexatória quando da apresentação da sua documentação, além de incutir o terceiro interessado na apresentação desses documentos de dubiedade. Assim, uma mulher com nome de homem e, vice-versa, causa mais assombro à sociedade do que o referido ajuste do prenome.

$\mathrm{O}$ artigo 55 da Lei 6.015/73, em seu parágrafo único, impede o registro de prenome que exponha o seu portador ao ridículo. A finalidade social desta norma se manifesta pela proteção à honra das pessoas, ou seja, ao seu direito personalíssimo.

Com efeito, mesmo que o ridículo tenha resultado de fato superveniente, como a inadequação entre sexo morfológico e psíquico, ou como a transgenitalização, o fundamento para a alteração do prenome será esse que o próprio legislador previu em situação diversa, mas que por analogia pode ser aplicado no caso dos transexuais.

Já o artigo 58, do mesmo diploma legal, permite a substituição por apelido público notório. Destaca-se que, sendo um indivíduo reconhecido publicamente por um prenome diverso, mesmo que ele seja atribuído a pessoas do sexo oposto ao que consta do seu registro civil, a lei garante, ainda que extensivamente, a substituição.

No que tange a alteração de sexo no registro civil, suscita maiores indagações, seja pela divergência de posicionamentos, seja pelos reflexos jurídicos advindos do ajuste de estado.

Inicialmente, destaca-se o artigo 1.604 do Código Civil ${ }^{55}$, que veda a alteração de estado no assento de nascimento, salvo, provando-se erro ou falsidade do registro. Nesse ponto, cabe analisar o referido dispositivo sobre dois aspectos distintos.

O primeiro, lembrando-se que parte dos especialistas argumenta que

\footnotetext{
$\overline{53}$ Art. 55. Quando o declarante não indicar o nome completo, o oficial lançará adiante do prenome escolhido o nome do pai, e na falta, o da mãe, se forem conhecidos e não o impedir a condição de ilegitimidade, salvo reconhecimento no ato. Parágrafo único. Os oficiais do registro civil não registrarão prenomes suscetíveis de expor ao ridículo os seus portadores. Quando os pais não se conformarem com a recusa do oficial, este submeterá por escrito o caso, independente da cobrança de quaisquer emolumentos, à decisão do Juiz competente.

${ }^{54}$ Art. 58. O prenome será definitivo, admitindo-se, todavia, a sua substituição por apelidos públicos notórios. Parágrafo único. A substituição do prenome será ainda admitida em razão de fundada coação ou ameaça decorrente da colaboração com a apuração de crime, por determinação, em sentença, de juiz competente, ouvido o Ministério Público.

${ }^{55}$ Art. 1.604. Ninguém pode vindicar estado contrário ao que resulta do registro de nascimento, salvo provandose erro ou falsidade do registro.
} 
a síndrome do transexualismo se manifesta antes do nascimento. Portanto, ao consignar o sexo no assento de nascimento, considerando-se apenas o aspecto anatômico, estar-se-á incorrendo em erro quando a identidade psicossexual não se harmonizar com o aspecto físico. Nesse passo, a alteração do estado sexual seria garantida em virtude do mencionado erro.

O segundo, em atenção à posição majoritária de que a transexualidade tem origem antes que a criança tenha discernimento, com possibilidade de surgir por volta dos dois primeiros anos de vida. Com efeito, o Estado reconhece essa patologia $\mathrm{e}$, por se tratar de um direito à saúde, garante o tratamento adequado, qual seja, a transgenitalização.

Ocorre que a intervenção cirúrgica constitui a primeira etapa do tratamento, o qual se completa com a adequação no registro civil, caso contrário, o transexual estaria relegado à condição de anomalia, psíquica e fisicamente mulher e juridicamente homem ou vice-versa, assim, sujeito ao desprezo, preconceito e isolamento social.

Lembrando-se, agora, que a saúde não está ligada à ideia de ausência de doenças, mas sim com o bem-estar físico, mental e social do indivíduo e, por conseguinte, trata-se de um direito fundamental social de aplicabilidade imediata, bem como um dever do Estado.

Logo, parece incongruente garantir a transgenitalização e, após, tolher o direito do transexual redesignado, abstendo-se, quando se deveria agir, fazendo persistir o problema de saúde, além de afrontar todos aqueles postulados já referidos anteriormente, os quais culminarão na inobservância da dignidade da pessoa humana.

Ainda, o artigo 1.604 do Código Civil deve ser analisado conjuntamente com o artigo $5^{\circ} \mathrm{da}$ Lei de Introdução às normas do Direito Brasileiro, o qual preceitua que na aplicação da norma, o juiz atenderá aos fins sociais a que ela se dirige e às exigências do bem comum.

A análise conjunta desses dispositivos revela que a norma coloca como exceção a imutabilidade do estado. Sendo a transgenitalização o ajuste àquela condição esdrúxula com que a natureza brindou os transexuais, a sua realização origina um erro no registro civil, uma vez que este não corresponde à nova realidade fática daquele indivíduo redesignado. Essa nova situação fática, em que pese ser superveniente àquela anteriormente registrada, corresponderá ao erro do registro anterior. 
Nessa esteira, a problemática dos transexuais exige uma abordagem conjunta com outras ciências, pois exige a compreensão da real condição dessas pessoas, da patologia pela qual estão acometidas, do tratamento médico adequado, bem como dos direitos que podem ser invocados na busca de uma solução justa.

Assim, deve-se destacar atenção à síndrome do transexualismo, aos direitos da personalidade, aos objetivos fundamentais da República Federativa do Brasil e da inviolabilidade dos direitos à vida, à liberdade, à igualdade, à saúde, e ao princípio da dignidade da pessoa humana. Lembrando-se que o desrespeito a esses preceitos também levaria à coisificação do sujeito, atingindo a dimensão básica da dignidade humana, acarretando, em consequência, à violação dos direitos humanos dos transexuais.

Por derradeiro, ao condicionar-se o direito do transexual de ser o que se é aos limites normativos de proteção à identidade, que inclui excluindo, estar-se-á limitando o campo de ação do direito, esta ciência que ataca o fato social e que não pode se furtar do excepcional, principalmente quando alimentado por mecanismos (dignidade da pessoa humana) que permitem extrair desse confronto uma solução justa e não apenas legalista.

Entende-se, dessa forma, que impedir o ajuste social após a transgenitalização faria persistir a perturbação psíquica do transexual, negando-lhe o direito à identidade sexual, acarretando-lhe uma situação vexatória, submetendo-lhe ao cárcere da sexualidade oposta a que acredita pertencer. Isso, quando o próprio Estado garante a adequação sexual. Consequentemente, ao tolher o direito de ajustar o assento de nascimento, estar-se-ia promovendo a exclusão social, negando-se a dignidade a essas pessoas e violando-se os direitos humanos.

\section{CONCLUSÃO}

A complexidade que envolve o tema impede de esgotá-lo em poucas palavras. Todavia, o operador do direito não pode fechar os olhos para a problemática dos transexuais, que exige uma abordagem multidisciplinar, de modo a alcançar, no silêncio da lei, uma solução justa.

Essa ideia de justiça deve guardar relação com a dignidade da pessoa humana, sendo buscada incessantemente, bem como garantida pelo aparato dos 
mais genuínos direitos do homem. Com base nesses direitos, desenhou-se, ao longo desse estudo, um caminho capaz de apontar soluções para a recente problemática.

Quando analisados os direitos que compóem a personalidade, observouse que comumente o transexual se apresenta de acordo com o sexo que acredita pertencer, sendo assim reconhecido no meio onde está inserido, o que possibilita alterar o seu prenome com base no apelido notório, na condição socialmente reconhecida. De outra banda, se após a transgenitalização não houver o consequente ajuste social, adequando o antigo prenome ao novo corpo, este exporá o seu portador à situação ridícula e vexatória, o que também viabiliza a pretensa alteração. Em ambos os casos se busca a dignidade, fim último dos direitos da personalidade, estes, separada ou conjuntamente analisados, também viabilizam essa modificação.

No caminho proposto, também estão os objetivos da República Federativa do Brasil, ou seja, princípios que devem nortear todo o aparato legal e constitucional. Quanto ao objetivo de uma sociedade livre, justa e solidária, entende-se pela união desses elementos quando da interpretação da norma constitucional. Com efeito, isso proporciona a liberdade de agir do transexual pela direção do seu bem-estar, dentro do justo, uma vez afastada a prática ilícita ou ilegal e respeitado o direito de terceiros. Ainda, com o respaldo dos seus semelhantes, solidários à causa e não com imposição de obstáculos. Ressaltando-se, igualmente, a inviolabilidade do direito à vida, à liberdade e à igualdade como forma de garantir a dignidade humana.

Ainda, entendendo a complexidade da redesignação sexual, percebe-se tratar da primeira fase do tratamento médico indicado ao transexual, o qual se completa com a adequação social desse indivíduo, alterando-se no registro civil, além do antigo prenome, também o seu estado sexual.

$\mathrm{O}$ direito à identidade sexual, tanto como um direito autônomo quanto como integrante dos direitos da personalidade, visa garantir a dignidade do indivíduo de ver resguardada a sua sexualidade e, por isso, deve ser invocado como uma base legal dos anseios dos transexuais.

Entendido o caráter patológico do transexualismo, torna-se indissociável a sua abordagem com o direito à saúde, direito fundamental social e de aplicabilidade imediata, que deve ser garantido e prestado pelo Estado a toda população, de forma contínua, adequada, eficiente e segura.

Solidariamente à saúde, enfoca-se o princípio da dignidade da pessoa humana, o qual engloba conceitos de vida digna e com qualidade, ou seja, a 
vida biológica qualitativamente desenvolvida, considerando as peculiaridades individuais da pessoa. Assim, a dignidade da pessoa humana, na qualidade de princípio fundamental, deve nortear, como diretriz a ser seguida e alcançada, todo o ordenamento constitucional e infraconstitucional. Para tanto, os direitos da personalidade, da saúde, bem como outros preceitos e garantias fundamentais são meios para a concretização desse postulado.

Sendo a transgenitalização permitida pelo Estado, após a sua realização, parece incongruente tolher o direito à adequação social, fazendo persistir a mácula da doença, expondo o transexual a situações vexatórias. Quanto aos Registros Públicos, ignorar essa nova realidade fática representaria atestar uma inverdade e incorrer em erro, subsistindo algo anômalo, juridicamente homem e fisicamente mulher e vice-versa.

Conclui-se, dessa forma, pela viabilidade do ajuste social dos transexuais redesignados. O caminho proposto com base nos direitos da personalidade, à saúde, à dignidade, sem esquecer dos fundamentos da República, assim como a inviolabilidade do direito à vida, à liberdade e à igualdade, conduz a essa certeza. Inclusive, no sentido de que tal alteração não venha precedida de qualquer ressalva que possa afrontar a dignidade dessas pessoas, atingindo, com isso, o fim social da norma e o respeito aos direitos humanos.

\section{REFERÊNCIAS}

ARAUJO, Luiz Alberto David. A proteção constitucional do transexual. São Paulo: Saraiva, 2000.

BAEZ, Narciso Leandro Xavier; BARRETO, Vicente. (Org.). Direitos humanos em evolução. Joaçaba: Ed. da Unoesc, 2007.

BAEZ, Narciso Leandro Xavier; CASSEL, Douglas. (Org.). A realização e a proteção internacional dos direitos humanos fundamentais. Joaçaba: Ed. da Unoesc, 2011.

BAEZ, Narciso Leandro Xavier; LEAL, Rogério Gesta; MEZZAROBA, Orides. (Coord.). Dimensões materiais e eficácia dos direitos fundamentais. São Paulo: Modelo, 2010. 
BEDIN, Gilmar Antônio. Os direitos do homem e o neoliberalismo. Ijuí: Ed. da Unijuí, 2002.

BEDIN, Gilmar Antônio. (Org.). Cidadania, direitos humanos e equidade. Ijuí: Ed. da Unijuí, 2012.

CANOTILHO, José Joaquim Gomes. Direito Constitucional e teoria da constituição. 7. ed. Coimbra: Almedina, 2003.

CHAVES, Antonio. Direito à vida e ao próprio corpo: intersexualidade, transexualidade, transplante. 2. ed. São Paulo: Revista dos Tribunais, 1994.

DINIZ, Maria Helena. O estudo atual do biodireito. São Paulo: Saraiva, 2001.

FARINA, Roberto. Transexualismo: do homem à mulher normal através dos estados de intersexualidade e das parafilias. São Paulo: Novalunar, 1982.

FERRAJOLI, Luigi. Principia iuris: Teoría del derecho y de la democracia. 2. Teoría de la democracia. Tradução Perfecto Andrés Ibáñez, Carlos Bayón, Maria Gascón, Luis Prietro Sanchís y Alfonso Ruiz Miguel. Madrid: Trota, 2011.

FLORES, Joaquín Herrera. Teoria crítica dos direitos humanos: os direitos humanos como produtos culturais. Rio de Janeiro: Lumen Juris, 2009.

LUCAS, Doglas Cesar; SPAREMBERGER, Raquel Fabiana L. Olhares hermenêuticos sobre o direito: em busca de sentido para os caminhos do jurista. Ijuí: Ed. da Unijuí, 2007.

LUCAS, Doglas Cesar. A identidade como memória biográfica do corpo e sua proteção jurídica: itinerários de um paradoxo. Sequência, Florianópolis, n. 65, p. 125-154, dez. 2012.

SANTOS, Boaventura De Sousa. Introdução: para ampliar o cânone do reconhecimento, da diferença e da igualdade. In: RECONHECER para libertar: os caminhos do Cosmopolitanismo multicultural. Rio de Janeiro: Civilização Brasileira, 2003.

SARLET, Ingo Wolfgang. Dignidade da pessoa humana e direitos fundamentais na Constituição Federal de 1988. Porto Alegre: Livraria do Advogado, 2001. 
SILVA, José Afonso da. Curso de direito constitucional positivo. 23. ed. rev. e atual. nos termos da reforma constitucional. São Paulo: Malheiros, 2004.

VIEIRA, Tereza Rodrigues. Mudança de sexo: aspectos médicos, psicológicos e jurídicos. São Paulo: Santos, 1996.

Recebido em: 15 de dezembro de 2013 Aceito em; 27 de março de 2015 